\title{
Article \\ Effect of Co-Surfactants and Pasteurization for Preservation of Natural Rubber
}

\author{
Sittiporn Punyanity ${ }^{1,}$, Rungsarit Koonawoot ${ }^{2}$, Anucha Raksanti ${ }^{3}$, Sakdiphon Thiansem ${ }^{4}$, Somchai Thamsutiwat ${ }^{5}$, \\ Surapattapong Kulltham ${ }^{4}$ and Tiwasawat Sirisoam ${ }^{1}$
}

1 Innovative Biomaterials and Medical Device Research Group, School of Medicine, Mae Fah Luang University, Chiang Rai, 57100, Thailand; punyanitya.s@gmail.com, tiwasawat_s@cmu.ac.th

2 Punyapanit Co., Ltd., 19/44, Singharaj Road, Tumbol Sriphum, Amphur Muang Chiang Mai, 50200, Thailand; koonawoot@yahoo.com

3 Science and Technology Research Institute, Chiang Mai University, Chiang Mai, 50200, Thailand; anuchabee@gmail.com

4 Department of Industrials Chemistry, Faculty of Science, Chiang Mai University, Chiang Mai, 50200, Thailand; thiansem.s@gmail.com, surapattanapong_k@cmu.ac.th

5 School of Law, Mae Fah Luang University, Chiang Rai, 57100, Thailand; somchai@mfu.ac.th

* Correspondence: punyanitya.s@gmail.com; Tel.: +66818818013

\begin{abstract}
This research was a study of the effect of addition linear alkylbenzene sulfonates (LAS), $\mathrm{NaHCO}_{3}$, and $\mathrm{NaCl}$ and pasteurization on the preservation of natural rubber (NR). The samples were collected from rubber plantations of Chiang Rai province which were added with three surfactants in samples already. Physical and chemical properties were evaluated using $\mathrm{pH}$, deterioration, viscosity, color, and odor. Then, the samples were stored at $28-30^{\circ} \mathrm{C}$ periods times of $0,15,30$, 45 , and 60 days. The experiment found that the color, viscosity, odor, and texture of NR samples were not spoiled after being preserved for 30 days but after 45 and 60 days found some coagulation of NR. In the case of non-preserved NR was found that spoiled NR in every period time range of 15-60 days. The $\mathrm{pH}$ testing found that increasing period times affect decreased $\mathrm{pH}$ value and increased viscosity due to salt of sulfate, carbonate, chloride, and thermal treatment of pasteurization which kill microorganisms and evaporated water. It concluded that the reagents were the process of cosurfactants with heat and frozen for increased effectiveness of anti-acid-producing bacteria and can use as short and long-term preservation of NR under the planting area condition of Thailand.
\end{abstract}

Keywords: Microorganisms; Natural Rubber; Hevea Brasiliensis; Surfactants; Pasteurization.

\section{Introduction}

Natural rubber (NR) derived from Hevea brasiliensis tree is a spontaneous colloid. The rubber particles dispersed in the liquid phase which is water. Rubber is an organic substance and after exposure to air. It will rot rapidly within 5-10 days [1,2]. The NR molecules break down into useless molecules. Rubber farmers have to rush to trade and receive with unfair prices. Because of the microorganism or bacteria that live in the air in the general. When the bacteria are contaminated with fresh NR and grow with the consumption of carbohydrates and proteins that make up the rubber composition. It then divides in multiples within approximately 20 minutes [3,4]. The obtained waste from consuming carbohydrates in rubber is small acid molecules that destroy the rubber content. The wastes derive from the consumption of protein inside NR become spoiled gas which produces a strong foul odor. At present, preservation of NR for processing into concentrated NR. It is the preservation of NR in a short time by using an ammonia solution range concentration of 0.1-0.4 wt $\%[5,6]$. Other substances may together use such as sodium sulfite, potassium hypochlorite, aromatic sulfonic acid, etc. In previous study, advantages of ammonia were [7] (1) inhibited the growth of bacteria. (2) the alkalinity of ammonia promoted the precipitation of rubber particles (3) could destroy the reactivity of metals such 
as magnesium in NR (4) did not cause coloring in NR but had disadvantages [8,9] were (1) volatile (2) the pungent smell was very strong and toxic to the user (3) evaporated into the atmosphere to cause environmental pollution (4) used in large amounts and must be used in conjunction with other substances make more expensive, so food preservation techniques and surfactants can adapt by slowing down or inhibiting natural rubber deterioration and microbial growth easy and environmentally friendly directly inactivating bacteria, yeast, enzymes, avoiding recontamination before and after processing [10].

Surfactants have a mechanism of action by adhering to the bacterial cell membrane and disrupting the structure of the cell membrane, causing the cell wall to leak. It is watersoluble and fat by precipitates in hard water. Surfactant molecules are composed of highly polar and non-polar parts together in a single molecule, called an amphiphilic molecule, like a phospholipid, which is the main component of cell membranes, thus destroying the function of the membrane. Cells got the non-polar of the molecule is usually straight-chain of hydrocarbons, branched, or may have a benzene loop, composed of a lipophilic side or polyether cord with oxygen at intervals to increase the hydrophobicity of the non-polar side [11]. The polar side of the molecule has many characteristics such as anionic surfactants and positively charged surfactants. Anionic surfactants are most commonly used as carboxylate, sulfonate, sulfate, or phosphate. Polar portions with cations of sodium or potassium or ammonium anionic surfactants usually have a $\mathrm{pH}$ of 8 to 10 that can cause skin irritation [12]. They are often used in conjunction with other anti-infective agents to enhance their action, such as stearate, lauryl sulfate, dodecylbenzene sulfonate, and cationic surfactant that can kill bacteria, both gram-positive and gram-negative. In addition, sodium bicarbonate has properties as a surfactant that changes its structure and inhibits the activity of microbial enzymes as well as detergents [13]. The addition of substances was increasing the osmotic pressure of substances such as salt to reduce the rate of water transmission between cells or increase the concentration of water in the cell as a solute in a solution that can inhibit microorganisms. The nature of the addition of solute into NR effects to the potential for growing bacteria. Ionic solutes such as $\mathrm{NaCl}$ or $\mathrm{KCl}$ are more inhibitors than non-ionic solutes such as sugars. Solute such as glycerol is different form unlike the salts and sugars which will rapidly permeate most bacteria but not yeast. [14]. Heat and frozen are the most commonly used method of food preservation. There is a various method of preservation by heating and freeze that depend on the type of materials. They manufactured in the terms of pasteurization and sterilization. However, for the effective, these processes must be carried out under a combination of strict temperature and time control to ensure the killing of pathogenic and non-pathogenic microorganisms $[15,16]$.

This research will study the effects of the combined method for preserved NR use of co-surfactants and pasteurization process for the development of preservation of NR for distribution and processing into rubber products with a method that is easy, cheap, nontoxic, and uncomplicated but can maintain the quality of NR.

\section{Materials and Methods}

\subsection{Materials}

The fresh natural rubber (NR) was obtained from Chiang Rai. NR was preserved with the surfactant of a mixture of Linear alkylbenzene sulfonates (LAS) (powder detergent) purchased from Macro Co. Ltd., sodium bicarbonate powder $\left(\mathrm{NaHCO}_{3}\right)$ was from SigmaAldrich and sodium chloride powder $(\mathrm{NaCl})$ were from Sigma-Aldrich at the constant ratio of 1:1:1 that dissolved in $100 \mathrm{ml}$ of distilled water at room temperature, stirred for 30 minutes. The obtained solution was prepared as $20 \% \mathrm{v} / \mathrm{v}$ of NR and this solution was placed at the bottom of the storage cup before collection from tapping the rubber tree after 2 hours later until NR flows into the cup. The obtained fresh NR mixed with the mixture solution that has been poured into the container. Then it was frozen below $4^{\circ} \mathrm{C}$ for 4 hours. After that NR was heated to $80^{\circ} \mathrm{C}$ for 30 minutes. The preserved natural rubber sealed in air tight container for prevent aeration. Finally, they were kept at a temperature of $4^{\circ} \mathrm{C}$ 
and characteristics such as $\mathrm{pH}$, viscosity, deterioration, odor, and color during the period $0,15,30,45$, and 60 days respectively.

\subsection{Characterizations and Analysis}

Characterization of NR were included pH testers (pH Tester Spear, Oakton 35634-40, Singapore) could be explained on the stability of NR. Viscosity of NR (DV-III+, Brookfield, USA) could be explained on flow behavior of NR. Physical observed such as deterioration, odor, and color.

\section{Results and Discussion}

Fig. 1 illustrates that the natural rubber tapping from the rubber tree has a milky white color and $\mathrm{pH}$ value approximately 6.398 (Fig. 2). The behavior of fluids was a nonNewtonian formed by dispersed rubber particles of different sizes. It is a colloidal state in the solvent (Fig. 3). The flow behavior of the non-homogeneous substance and the fluid undergoes shear stress which it can flow well. The research aimed to preserve the condition of NR from spoilage by developing and improving the process of preservation with a non-ammonia solution which causes bad odor and air pollution to the environment is alternative by nontoxic substances to humans and the environment. While most previous research, it was found that if ammonia content was lower than $0.05 \%$ by weight, bacteria growth rate was higher since latex has a $\mathrm{pH}$ increased from 6.398 to 8, making it suitable for the growth of bacteria. Therefore, general research requires a higher than $0.1 \%$ ammonia content [17].

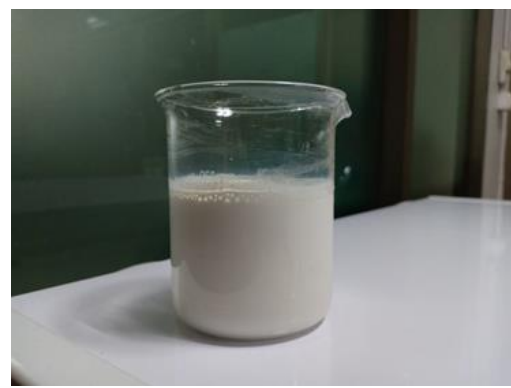

Figure 1. NR (Before preserved).

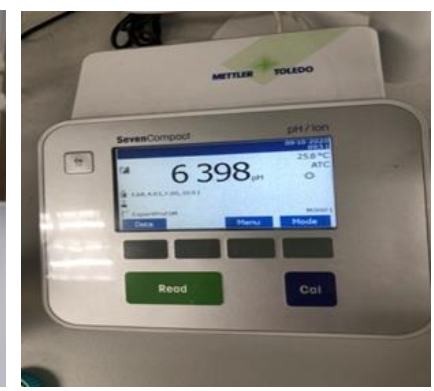

Figure 2. $\mathrm{pH}$ of NR.

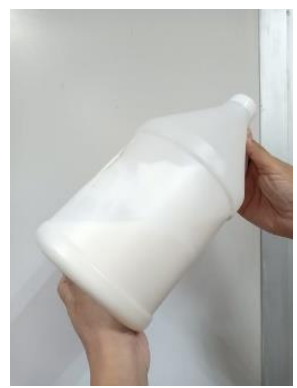

Figure 3. Viscosity of NR.

Increasing the ammonia content in NR could decrease the bacterial growth in the fresh latex. Nonetheless, ammonia has the disadvantages as mentioned above. Therefore, this research found that the addition of LAS with $\mathrm{NaHCO}_{3}$, and $\mathrm{NaCl}$ to adjust the $\mathrm{pH}$ above 8 until the $\mathrm{pH}$ was 14 at the initial time. The results showed that the viscosity of fresh latex had a viscosity of approximately 12-15 cP [18] and the preserved NR had viscosity higher than non-preserved as $603 \%$. This indicated that the viscosity of the processing of preserved NR was significantly higher than non-preserved NR and had a viscosity in the range of $80-100 \mathrm{cP}$ [19]. However, the effect of the increase viscosity may be cause by the addition of salts of three different surfactants and the process of cool and heat treatment. One of the reasons the increase viscosity may be cause the amount of dissolve surfactant and suspend coexisting with the rubber particles which contains the salts of the sulfate, carbonates, and chlorides group. The functional groups of the three substances bind with the poly-isoprene of rubber chains and the pasteurization to kill bacteria and control the temperature has results in the water evaporation from the molecular structure of the latex. This process causes water to evaporate from the molecular structure of the latex to a higher viscosity. Therefore, natural rubber was able to sustain a longer shelf life and found that periods over 15, 30, 45 and 60 days, the $\mathrm{pH}$ decreased to 12, 11, 10 and 9, respectively (Table 1 ). 
Table 1. Properties of preserved NR with co-surfactant and pasteurization by before and after preservation under different preservation period.

\begin{tabular}{|c|c|c|c|c|c|c|c|c|c|c|}
\hline \multirow{2}{*}{$\begin{array}{c}\text { Preservation } \\
\text { period } \\
\text { (Days) }\end{array}$} & \multicolumn{2}{|c|}{ pH } & \multicolumn{2}{|c|}{$\begin{array}{c}\text { Viscosity } \\
\text { (cP) }\end{array}$} & \multicolumn{2}{|c|}{ Color } & \multicolumn{2}{|c|}{ Deterioration } & \multicolumn{2}{|c|}{ Odor } \\
\hline & Before & After & Before & After & Before & After & Before & After & Before & After \\
\hline 0 & 6.398 & 14 & $12-15$ & 90 & White & White & None & None & None & None \\
\hline 15 & 6.398 & 12 & Spoiled & 95 & $\begin{array}{l}\text { Light } \\
\text { brown }\end{array}$ & White & Gelation & None & Foul & None \\
\hline 30 & 6.398 & 11 & Spoiled & 97 & $\begin{array}{l}\text { Light } \\
\text { brown }\end{array}$ & White & Flocculated & None & Foul & None \\
\hline 45 & 6.398 & 10 & Spoiled & 100 & Black & White & Coagulated & None & Foul & None \\
\hline 60 & 6.398 & 9 & Spoiled & 105 & Black & White & Coagulated & $\begin{array}{l}\text { Some } \\
\text { coagulated }\end{array}$ & Foul & None \\
\hline
\end{tabular}

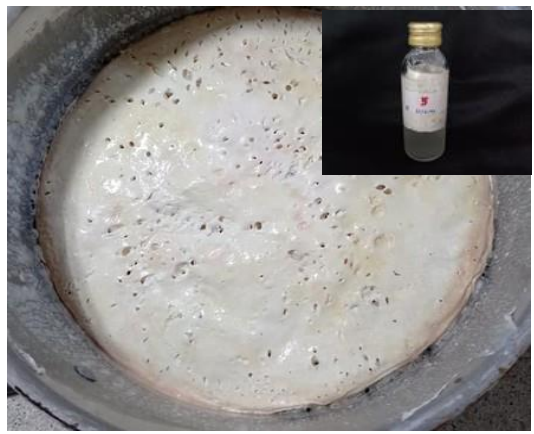

Figure 4. Spoiled NR.

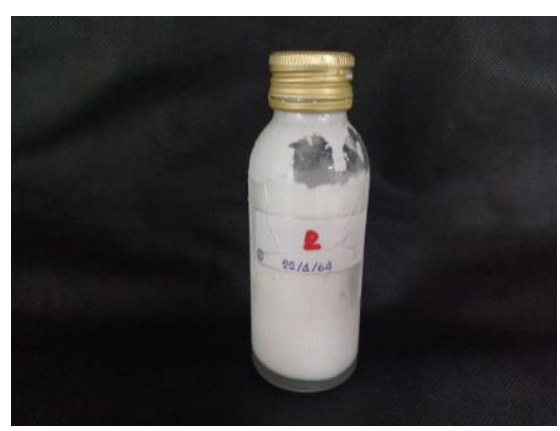

Figure 6. Preserved NR for 30 days (arrow).

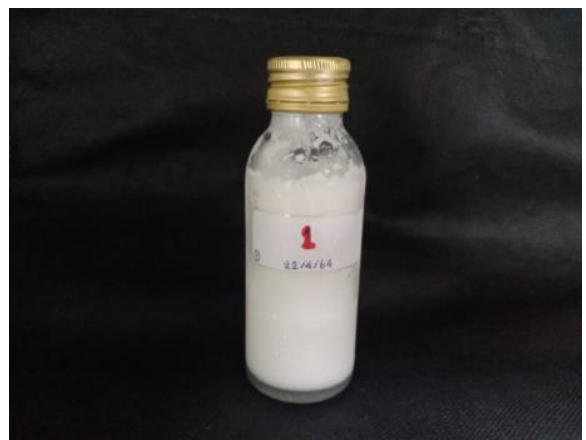

Figure 5. Preserved NR for 15 days.

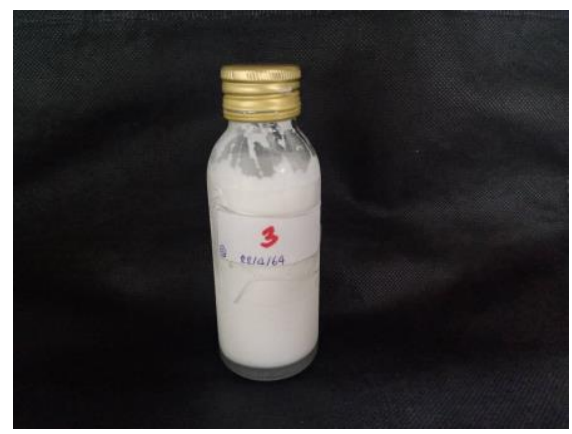

Figure 7. Preserved NR for 45 days.

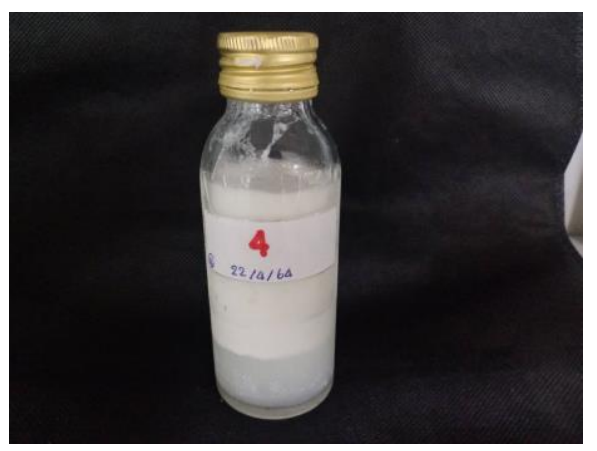

Figure 8. Preserved NR for 60 days. 
As the rubber particles begin the deterioration of their colloidal. However, the other physical appearance compared with unpreserved NR such as color, deterioration and odor. This result found that preserved NR that stabilized and unchanged color (Fig. 8) until 60 days, no foul odor and no coagulation after 30 days (Fig. 6), but some coagulation begins due to the separation of the concentrate latex layer, separating the floating layer on top of total NR layer for 45 and 60 days (Fig. 7 and 8), while the non-preserved NR change color from white to light brown and gelation (Fig. 4) because of spoilage, foul odor, and eventually black due to growing fungi and rubber coagulation. Small pellets until they become larger due to the deterioration and growth of bacteria.

Moreover, antibiotic resistant bacteria have been observed by monitoring of bacteria growth show in Fig. 9. After 30 days ago, the preserved NR and non-preserved were swap on algae disk, the result of bacterial culture show total plate count of preserved NR was below 1.0 colony forming units per milliliter $(\mathrm{cfu} / \mathrm{ml})$. It can be indicated that the preserved solution which prepared from LAS with $\mathrm{NaHCO}_{3}$, and $\mathrm{NaCl}$ has effective to antibiotic resistant. Fig.10 show the antibiotic sensitivity test to find out the effective antibiotic resistant of samples solution. Bacteria are not able to grow around the sample of preserve solution, it relates to the result of Fig. 9.

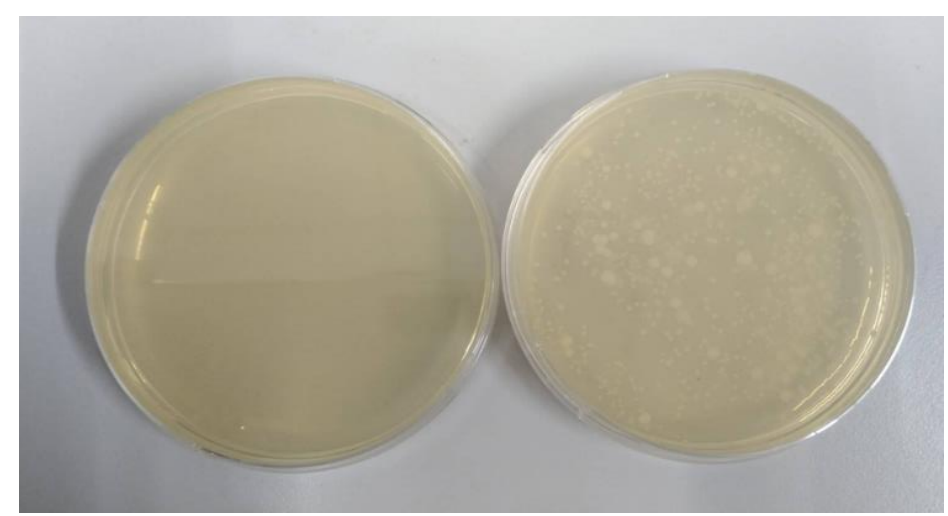

(a)

(b)

Figure 9. Comparison of the growth of bacteria in; (a) preserved NR and (b) non-preserved after stored 30 days.

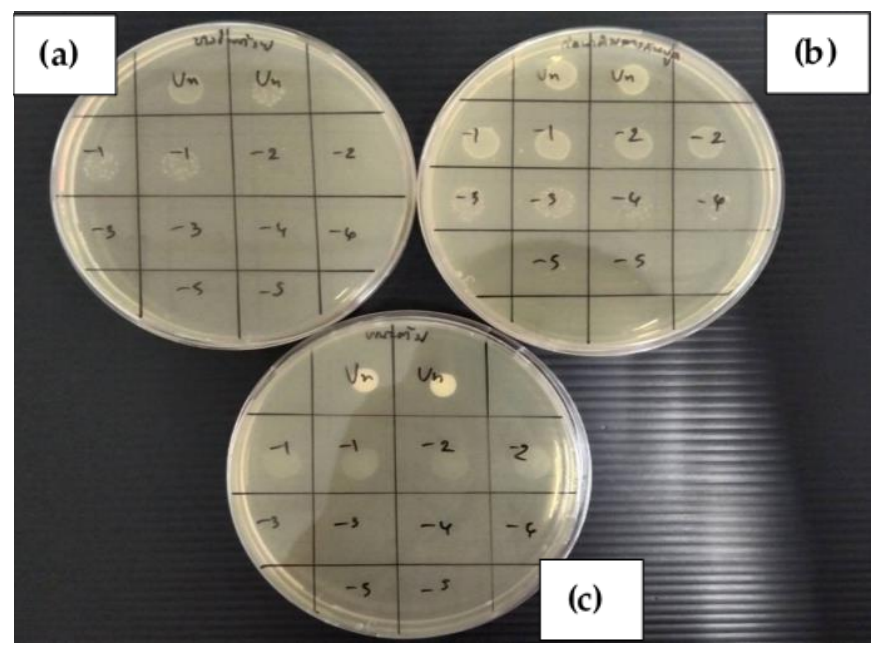

Figure 10. The antibiotic sensitivity test; (a) fresh NR, (b) preserved NR and (c) non-preserved NR.

\section{Conclusions}


This research found that the combination of aluminum sulfate with sodium bicarbonate and sodium chloride in the same weight ratio for all 3 types to preserved NR in the cosurfactant with pasteurization process. The frozen temperature was below $4^{\circ} \mathrm{C}$ for 4 hours and heated to $80^{\circ} \mathrm{C}$ for 30 minutes. It was found that sufficient to preserve the natural latex for up to 60 days and was effective in reducing the acidity of NR by alkalinity of surfactant. The results derived in the present study suggest that this process presented here is an alternative route and practical model for development of preserved NR used as a short and long term.

Acknowledgments: This work was supported by fund Innovative Biomaterials and Medical Device Research Group, Mae Fah Luang University and we sincerely would like to thank for the warm willingness support from Assistance prof. Sakdiphon Thiansem, Department of Industrial Chemistry, Faculty of science, Chiang Mai University.

\section{References}

[1] Hans Janecka. Prevention of Deterioration Center Division of Chemistry and Chemical Technology National Academy of SciencesNational Research Council in The aging of Natural and synthetic rubber and rubber products, An Annotated Bibliography Compiled, February 1964, 2101 Constitution Avenue DDC-IRA B, Washington, D.C.

[2] Intapun, J., Sainte-Beuve, J., Bonfils, F., Tanrattanakul, V., Dubreucq, E. and Vaysse, L. Effect of microorganisms during the initial coagulum maturation of hevea natural rubber. J Appl Polym Sci, 2010, 118, 1341-1348.

[3] Atagana, H.I., Ejechi, B.O. and Ayilumo, A.M. Fungi associated with degradation of wastes from rubber processing industry. Environ Monit Assess 1999, 55, 401-408.

[4] Atagana, H.I., Ejechi, B.O. and Ogodu, M.I. Bacteria associated with degradation of wastes from rubber processing industry. Environ Monit Assess 1999, 59, 145-154.

[5] L. Tarachiwin, J. Sakdapipanich, and Y. Tanaka, Rubber Chem. Technol. 76 (2003)1177.

[6] L.Tarachiwin, J. Sakdapipanich, and Y. Tanaka, Rubber Chem. Technol. 76 (2003)1185.

[7] Lowe, J. S. 1960. Transactions of the Institutions of the Rubber Industry 36: 225.

[8] A. S. COOK. Vol .6. The Short-Term Preservation of Natural Latex.

[9] Bishop, R. O. \& Fullerton, R. G. ,Latex preservation and shipment. Plant. Manual, 1932, 4, A-1.

[10] Food Safety A Practical and Case Study Approach, Method of Food Preservation, Edited by Anna Mc Elhatton and Richard J. Marshall, 2007, springer.

[11] Christofi N, Ivshina I .Microbial surfactants and their use in soil remediation. In: Fingerman M, Nagabhushanam R (eds) Bioremediation of aquatic and terrestrial ecosystems. Science, Enfield, NH, 2005, pp 311-327.

[12] Christofi N, Ivshina IBJ. Microbial surfactants and their use in field studies of soil remediation. Appl Microbiol, 2002, 93(6):915929.

[13] Shapton, D.A. and Shapton, N.F., 1991, Principles and Practices for the Safety Processing of Foods, Butterworth, London.

[14] Booth, I.R., 1998, Bacterial Responses to Osmotic Stress: Divers mechanisms to Achieve a Common Goal in "The Properties of Water in Food". ISOPOW-6.

[15] Holsinger, V. H., Rajkowski, K. T. and Stabel, J. R., Milk pasteurization and safety: a brief history and update. Scientific and Technical Review of the office International des Epizooties (paris) 1997, 16 (2), 441-451.

[16] Heldman, D.R. and Lund, D.B., 1992, Handbook of Food Engineering, Marcel Dekker, New York.

[17] Sirinapa S.and Sa-Ad R., Effect of field natural rubber latex with different ammonia contents and storage period on physical properties of latex concentrate, stability of skim latex and dipped film, Physics Procedia 2009, 2, 127-134.

[18] Jatuporn S., RHEOLOGICAL PROPERTIES OF NATURAL RUBBER LATEX, A Thesis Submitted in Partial Fulfillment of the Requirements for the Degree of Master of Engineering in Polymer Engineering Suranaree University of Technology Academic Year 2006.

[19] Anyawee P. and Phanida S., The use of pasteurization to control microbial growth in rubber latex, J. Food Agric. Sci, 2015,1, 131135 